\title{
Evidence of accelerated ageing in clinical drug addiction from immune, hepatic and metabolic biomarkers
} Albert Stuart Reece ${ }^{1,2}$ Address: ${ }^{1}$ Southcity Family Medical Centre, 39 Gladstone Rd., Highgate Hill, Brisbane, Queensland, 4101, Australia and ${ }^{2}$ Herston Medical School,
Herston Rd, Herston, University of Queensland, Brisbane, Queensland, Australia

Email: Albert Stuart Reece - sreece@bigpond.net.au

Published: 24 September 2007

Immunity \& Ageing 2007, 4:6 doi: 10.1 I86/1742-4933-4-6

This article is available from: http://www.immunityageing.com/content/4/I/6

(c) 2007 Reece; licensee BioMed Central Ltd.

This is an Open Access article distributed under the terms of the Creative Commons Attribution License (http://creativecommons.org/licenses/by/2.0), which permits unrestricted use, distribution, and reproduction in any medium, provided the original work is properly cited.
Received: I March 2007

Accepted: 24 September 2007

\begin{abstract}
Background: Drug addiction is associated with significant disease and death, but its impact on the ageing process has not been considered. The recent demonstration that many of the items available in routine clinical pathology have applicability as biomarkers of the ageing process implies that routine clinical laboratory parameters would be useful as an initial investigation of this possibility.
\end{abstract}

Methods: 12,093 clinical laboratory results 1995-2006 were reviewed. To make the age ranges of the medical and addicted groups comparable the age range was restricted to $15-45$ years.

Results: 739 drug addicted (DA) and 5834 general medical (GM) age matched blood samples were compared. Significant elevation of immune parameters was noted in the C-reactive protein, erythrocyte sedimentation rate, total lymphocyte count, serum globulins and the globulin:albumin ratio $(P<0.01)$. Alanine aminotranferase, creatinine, urea, and insulin like growth factor-I were also significantly higher $(P<0.01)$ in the DA group. Albumin, body mass index and dihydroepiandrosterone sulphate were unchanged and cholesterol was lower (all $P<0.05$ ).

Conclusion: These data demonstrate for the first time that addiction is associated with an altered profile of common biomarkers of ageing raising the possibility that the ageing process may be altered in this group. Infective and immune processes may be centrally involved. They suggest that addiction forms an interesting model to further examine the contribution of immune suppression and hyperstimulation to the ageing process.

\section{Background}

Addictive disorders are well known to be associated with a high level of physical and psychological disorders [1]. Most chronic chemical addictions are also associated with very elevated rates of mortality [2] which have been estimated to be $10-70[3,4]$ times that of non-clinical populations. Addictive drugs are known to impair cell growth and division [5-7] and therefore might be presumed to impact particularly dividing cells such as stem and progenitor cell pools $[8,9]$. They are also known either singly or in combination to potentiate apoptosis [10-14] thereby adding to this effect. Ageing medicine has recently emerged as a distinct scientific discipline. The cellular hypothesis of ageing suggests that the ageing phenotype of the organism is associated with cellular correlates of age related change including cell loss, reduced rates of cell renewal, and higher numbers of senescent, marginally functional, and non-replicative cells in the tissues $[15,16]$. Therefore if the growth inhibitory effects of addiction occur throughout the organism, one might reasonably 
expect that signs of accelerated ageing may be evident. Such a putative progeroid effect might be expected to underlie the elevated rates of morbidity and mortality observed clinically amongst addicts in much the same way as they do in geriatric populations. In this connection it is relevant that a variety of changes consistent with such a pro-ageing effect [17] have been reported both from our own clinic and elsewhere, and relating to neuropsychiatric disorders [18-20], calcific [21] and degenerative[22] arteriosclerosis, osteoporosis[23,24], oligospermia $[25,26]$, hair greying [27] and severe dental and periodontal pathology $[28,29]$. Consideration of all of the clinical expressions of this generic hypothesis of the toxicology of addiction is beyond the scope of the present investigation.

The immune system in particular is central to a consideration of ageing. The immune system of drug dependent individuals is known to be suppressed, dysfunctional and hyperstimulated [30-34], and these perturbations are the subject of on-going enquiry. Not only does the immune system itself demonstrate age related change $[35,36]$, but the ready access of its cells and cytokines to most parts of the body including the CNS in many inflammatory disease states, suggests that dysfunction in this system might potentially be an important mediator and contributor to putative age related processes including atherosclerotic [37] and neurodegenerative [38] disorders as well as a major source of free radicals [39]. Some chemical addictions have also been associated with free radical generation $[40,41]$.

The potential implications of an improved understanding of the pathophysiology of addiction may have several clinically relevant implications. There is intense interest from the National Institutes of Ageing and others in the development of anti-ageing medicines (such as resveratrol and diaformin) [42] and it may be that such agents come to have a role in the treatment of the addictions. Conversely research in anti-ageing medicines has fuelled vigorous interest in various biomarkers as surrogate end points for otherwise lengthy clinical trials of putative agents [43]. Conveniently many of the common biomarkers are readily available in clinical pathology laboratory parameters in widespread use. If the classical chemical addictions are shown to accelerate ageing, then clearly there may be a role for their antagonists (such as the opioid antagonists naltrexone and nalmefene and cannabinoid antagonists such as rimonabant) which are largely pro-mitotic, as anti-ageing therapies if a deleterious effect on cancer can be avoided. And clearly a better understanding of the mechanism by which the various chemical addictions act to induce the aged phenotype may enhance our understanding of the basic pathophysiology of the ageing process itself, including gametotoxic and developmental implications.
My clinic sees both medical patients and patients addicted (mainly to opiates) and so provides an opportunity to compare relevant states of health and disease in these two populations. The present paper is presented as an initial clinical study of this subject and is intended to stimulate further investigative interest in the possible progeroid effects of addiction based on readily available clinical information relating to infective episodes and laboratory pathology.

\section{Methods}

\section{Patient Recruitment, Survey and Sampling}

This primary care medical centre operates in inner city Brisbane and sees both general medical (GM) and drug addicted (DA) patients. Most of our work involves the treatment of opiate addicted persons, and this is undertaken predominantly with the buprenorphine/naloxone combination sublingual tablet. Blood samples were taken opportunistically on patients as part of their routine clinical care.

\section{Laboratory Analysis}

Specific haematological and biochemical data of interest was requested from our commercial clinical pathology laboratories for our patients in the period 1995-2006. Assays were done by standard clinical laboratory methods. The clinical laboratories used were Queensland Medical Laboratories (QML) and Mater Hospitals (MAH) Pathology Laboratories both in Brisbane, Queensland, Australia. Both laboratories are accredited within Australia by the National Association of Testing Authorities (NATA) to the current Australian medical laboratory standards (AS-15189), and QML is accredited to ISO 9001 the international clinical laboratory standard. $96 \%$ of the work was done at QML, and 4\% at MAH. GM and DA samples were sent equally to both laboratories. All pathology samples were sent to QML prior to June 2006, and to MAH after that time. Where available results from both sites were combined unless the normal range or distribution of the results were significantly different so that artefactual differences were introduced into the analysis. In such cases, only the larger dataset was used. When data from the two laboratories was combined, care was taken not to alter the pattern of results. Reported data for albumin were based only on QML data. In other cases data from the two laboratories was directly combined. The normal ranges for the two laboratories are included in Table 1. Data for DHEAS and IGF1 are not included as they are age and sex dependent and vary substantially over the lifespan. The normal ranges for these two parameters in the two laboratories were thought to be similar.

\section{Data Analysis and Statistics}

Data was entered into Excel spreadsheets. Data is listed as mean \pm S.D. or S.E. as indicated. Statistical analysis was 
Table I: Normal ranges of clinical laboratory parameters

\begin{tabular}{lcc}
\hline PARAMETER & QML Range & MAH Range \\
\hline CRP $(\mathrm{IU} / \mathrm{l})$ & $\mathrm{I}-6$ & $\mathrm{I}-6$ \\
ESR $(\mathrm{mm} / \mathrm{hr})$ & $\mathrm{I}-25$ & $\mathrm{I}-25$ \\
Albumin $(\mathrm{g} / \mathrm{l})$ & $35-50$ & $33-47$ \\
Globulins $(\mathrm{g} / \mathrm{l})$ & $20-40$ & $20-40$ \\
Lymphocytes $\left(* 10^{9} / \mathrm{l}\right)$ & $1.1-4.0$ & $1.0-4.8$ \\
ALT $(\mathrm{U} / \mathrm{l})$ & $0-45$ & $5-45$ \\
Cholesterol $(\mathrm{mmol} / \mathrm{l})$ & $3.1-6.5$ & $2.6-5.5$ \\
Urea $(\mathrm{mmol} / \mathrm{l})$ & $2.0-7.0$ & $3.0-8.0$ \\
Creatinine $(\mathrm{mcmol} / \mathrm{l})$ & $40-110$ & $70-120$ \\
\hline
\end{tabular}

performed using the EpiInfo program obtained from Centres for Disease Control for Chi squared comparisons of paired categorical data to calculate relative risks, 95\% confidence intervals and significance levels; quantitative data was analyzed using T-tests performed in Microsoft Excel; and graphs were presented using the statistical software package "Statistica" on a Dell personal computer. Clinical pathology results were made available in electronic format. DA were sorted from GM patients by the presence of a Hepatitis C test, a test which is limited almost completely to use in DA patients. No data (such as outliers) was excluded from the analysis.

\section{Ethical Approval}

All procedures and studies were consistent with good clinical practice as defined by the National Health and Medical Research Council and the Declaration of Helsinki and were approved by the approved by the Human Research Ethics Committee of the Southcity Family Medical Centre. Patients gave informed consent to participation in the study. No external source of funding was involved.

\section{Results}

The age and sex distribution of the two groups is given in Table 2. In this study 798 DA and 11295 GM blood samples from patients of all ages were available for analysis. However, as indicated in Table 2 again problems of age disparity between the two groups were encountered. Therefore the age range was restricted to $15-45$ years, leaving 739 and 5834 samples for consideration. The resulting mean ages $( \pm$ S.E. $)$ were $30.92 \pm 0.24$ and $30.74 \pm 0.11$ years respectively (P - N.S.).

The present data was not linked to a detailed drug use history. DA patients presented for management of opiate addiction, where the primary substance of abuse was $86 \%$ heroin, $12 \%$ morphine, $1 \%$ buprenorphine and $1 \%$ methadone. More detailed information relating to drug use by this cohort has been previously published and is included for convenience in Table 3. Only $1 \%$ of each group was HIV positive.
Table 2: Demographic data

\begin{tabular}{|c|c|c|c|}
\hline PARAMETER & ADDICTS & MEDICAL & $\begin{array}{c}\text { (TOTAL/) } \\
\text { SIGNIFICANCE }\end{array}$ \\
\hline $\begin{array}{l}\text { All Sample Size } \\
\text { (Total) }\end{array}$ & 798 & 11295 & 12093 \\
\hline Age as Mean(SD) & $31.95(8.39)$ & $46.66(19.18)$ & $<0.0001$ \\
\hline $\begin{array}{l}\text { Sample Size }<45 \\
\text { Years (Total) }\end{array}$ & 739 & 5834 & 6573 \\
\hline Age & $30.92(6.52)$ & $30.74(8.63)$ & N.S. \\
\hline$\%$ Male & $73.5 \%$ & $54.3 \%$ & $<0.0001$ \\
\hline
\end{tabular}

Data as mean \pm S.D.

A study of this nature is predicated on being able to reliably separate intravenous drug using (IVDU) DA from GM. Review of 100 samples from each group found a $1 \%$ and $3 \%$ error rate respectively in group assignment based on HCV status. Furthermore the HCV positivity rate in the DA group was $69 \%$, which accords well with $70 \%$ as previously found in studying DA in our clinic, suggesting minimal contamination and dilution of the IVDU DA group.

Figures 1 and 2 demonstrates the lifetime trends for the variables of interest, namely CRP, ESR, globulins, albumin, globulin/albumin ratio, total lymphocyte count, ALT, cholesterol, urea, creatinine, dihydroepiandrosterone (DHEAS) and insulin like growth factor-1 (IGF1) together with their lines of best fit. Similar curves may be generated for the period of interest 15-45 years and these are included as Additional File 1. These two figures are best viewed together. The data is quantified in Table 4, and the relative fractions which are elevated either above normal or beyond a certain limit are given in Table 5 .

There is little relative change in the CRP, although it was shown that $52.6 \%$ of DA Vs. $37.7 \%$ of GM had elevated $\mathrm{CRP}(\mathrm{OR}=1.84$, CI $1.30-2.60 ; \mathrm{P}<0.0005)$. The ESR showed an obvious rise in the $<45$ years comparison confirmed by a higher mean $( \pm$ S.E. $) 11.34 \pm 1.29)$ vs. $8.75 \pm$ $0.35, \mathrm{P}=0.05$, with more elevated values $(7.7 \%$ Vs. $4.1 \%$, $\mathrm{OR}=1.98, \mathrm{OR}=1.98, \mathrm{CI} 1.00-3.87 ; \mathrm{P}<0.05)$. Serum globulins showed an obvious rise with age with a higher mean in DA $30.33 \pm 0.19$ Vs. $29.47 \pm 0.05$ with $14.8 \%$ Vs. $9.3 \%$ elevated $(\mathrm{OR}=1.70$ CI $1.32-2.18 ; \mathrm{P}<0.002)$. The albumin levels were identical in both groups, so the globulin/albumin ratio rose in DA over both the total lifespan and particularly in the $<45$ years group $(14.8 \%$ Vs. $9.3 \%$ $>6.5, \mathrm{OR}=1.69$, CI $1.21-2.21 ; \mathrm{P}<0.002)$. The lymphocyte count in the GM patients showed the usual decline with age. However, this was absent from the DA group, where the lymphocyte count remained stable throughout life. Hence the mean lymphocyte count was higher in the DA $2.41 \pm 0.03$ Vs. $2.26 \pm 0.01 \times 109 / 1$ and 
Table 3: Drug use

\begin{tabular}{|c|c|c|}
\hline PARAMETER & ADDICTS & MEDICAL \\
\hline \multicolumn{3}{|l|}{ Dose \& Duration } \\
\hline Cigarette Numbers & $16.08(10.87)$ & $4.36(8.12)^{* * *}$ \\
\hline Cigarette Duration (Yrs) & $13.83(8.62)$ & $3.77(8.145)^{* * *}$ \\
\hline Alcohol Size (g/d) & $8.65(21.51)$ & $1.77(10.23)^{* * *}$ \\
\hline Alcohol Duration (Yrs) & $2.97(5.84)$ & $0.96(3.08)^{* * *}$ \\
\hline Cannabis Size $(g / d)$ & $2.71(5.25)$ & $0.34(1.56)^{* * *}$ \\
\hline Cannabis Duration (Yrs) & $7.27(7.57)$ & $0.81(3.24)^{* * * *}$ \\
\hline Heroin Size (g/d) & $0.57(1.01)$ & $0.00 * * *$ \\
\hline Heroin Duration (Yrs) & $8.97(6.92)$ & $0.00 * * *$ \\
\hline Morphine Size (g/d) & $0.05(0.20)$ & $0.00^{* * * *}$ \\
\hline Morphine Duration (Yrs) & $1.19(4.12)$ & 0.00 **** \\
\hline Methadone Max. Dose & $27.53(47.19)$ & $0.00 * * *$ \\
\hline Methadone Duration (Yrs) & $1.21(3.05)$ & $0.00 * * *$ \\
\hline Amphetamine Size $(\mathrm{g} / \mathrm{d})$ & $0.55(I .5 \mathrm{I})$ & $0.02(0.15)^{* * * *}$ \\
\hline $\begin{array}{l}\text { Amphetamine Duration } \\
\text { (Yrs) } \\
\text { Dose-Duration Products }\end{array}$ & $1.89(4.29)$ & $0.19(1.31)^{* * *}$ \\
\hline Cigarette Index (Cig-Yrs) & $256.25(217.70)$ & $69.26(164.68)^{* * * *}$ \\
\hline Alcohol Index (g-Yrs) & $73.49(219.19)$ & $21.89(132.79)^{*}$ \\
\hline THC Index (g-Yrs) & $28.99(62.87)$ & $3.31(14.53)^{* * * * *}$ \\
\hline Heroin Index (g-Yrs) & $5.92(11.06)$ & $0 * * * *$ \\
\hline Morphine Index (g-Yrs) & $0.39(1.57)$ & $0 * * *$ \\
\hline Methadone Index (mg-Yrs) & $114.26(373.82)$ & $0 * * * *$ \\
\hline Amphetamine Index (g-Yrs) & $1.39(10.17)$ & $0.19(1.31)^{* * * * *}$ \\
\hline
\end{tabular}

Data as Mean ( \pm S.D.)

$*-\mathrm{P}<0.05$

$* * *-\mathrm{P}<0.001$

$* * * *-P<0.0001$

more DA had a lymphocyte count above $2.5 \times 109 / 1$ (37.3\% Vs. 31.8\%, OR = 1.27, CI 1.06-1.53; $\mathrm{P}<0.01)$.

The body mass index was not different between the two groups (Additional File 1, Table 5). ALT is significantly higher in the DA group by all measures. The mean DA cholesterol $(4.48 \pm 0.04 \mathrm{mmol} / \mathrm{l})$ is less than that in GM $(4.77 \pm 0.14 ; \mathrm{P}<0.0001)$, but as noted the albumin is unchanged between the two groups. The urea and creatinine are both higher in DA, and elevated ratios of urea to creatinine are more common in the DA group $11.0 \%$ Vs. $5.3 \%(\mathrm{OR}=2.78, \mathrm{CI} 2.11-3.65 ; \mathrm{P}<0.0001)$.

IGF1 was higher in the DA group. The rate of IGF1 above 30 was greater in $\mathrm{DA}(\mathrm{OR}=3.66, \mathrm{CI} 1.70-7.91 ; \mathrm{P}<$ $0.002)$. DHEAS levels were not different overall, or in any of the age and sex groups examined. As it is an androgen, with higher levels in males particularly during adult years, a detailed graphical analysis of these data is presented in Figure 3.

\section{Discussion}

These data demonstrate in HIV negative populations that addicted patients have a clinical pathological profile of immune stimulation (higher ESR, CRP, globulins, globulin:albumin ratio, lymphocyte count) in the setting of hepatic (higher ALT and lower cholesterol) and renal (higher urea, creatinine and urea:creatinine ratio) dysfunction. The body mass index and albumin were similar in the two groups suggesting nutritional adequacy in the DA group. The DHEAS showed no overall between group variation, but interesting differences in patients less than 45 years. Interestingly the IGF1 appeared better in the DA group.

The major finding of this study is that as these various parameters have been suggested as important biomarkers of the ageing process, they form together a highly suggestive pattern of findings that the ageing process in addiction might be following a different time trajectory from medical patients. They also suggest that the known immune derangements of addiction may be playing a role in the observed systemic perturbations.

There is a large literature particularly coming from the study of centenarians in Italy which posits that chronic antigenic stress exerts a strain on the immune system, uses up all the naïve T-cells and causes long term CD4 and CD8 memory cells to accumulate [44-52]. In part this is believed to occur via free radical stimulation of P16INK4A dependent apoptosis [53]. It is fascinating to consider that all these circumstances pertain in addiction. In the absence of HIV infection chronic antigenic stimulation in addiction can originate from dental, bronchial and cutaneous foci, from chronic hepatic inflammation and viral shedding, from the use of drugs, and the endobronchial absorption and intravascular injection of particulate substances all of which are directly active on immune cells and the injection of particulate impurities including microbial organisms and antigens. Hence the situation in addiction closely parallels that in ageing, as both demonstrate chronic antigenic overload, immune stimulation, immunosuppression and signs of accelerated ageing. Hence the immune system may not only be a spectator in both the ageing process and in addiction, but a major effector of time dependent decay. Clearly these parallels require more detailed prospective investigation.

It is also interesting to speculate on the interrelationship between the immune stimulation and solid organ dysfunction documented in the pathological study. The liver in particular is known to harbor a substantial body of immune (Kupffer) cells and endothelial cells in its sinusoids, and their interaction with and response to systemic alterations may be more than passive. Both the immune and endothelial components are believed to be important in modern theories of ageing. This is particularly relevant in a context where the liver is receiving long term irritation through alcohol, intravenous injection, drug detoxification or chronic viral infection. Clearly several drug related factors must inform the use of the ALT as an uncompli- 
Table 4: Clinical laboratory biomarkers in addiction $<45$ years of age

\begin{tabular}{|c|c|c|c|}
\hline & ADDICTS & MEDICAL & $P$ \\
\hline Age (<45 Years) & $30.92(0.24)$ & $30.74(0.11)$ & N.S. \\
\hline $\mathrm{CRP}(\mathrm{mg} / \mathrm{L})$ & $10.15(2.11)$ & $7.57(0.55)$ & N.S. \\
\hline ESR & II.34 (I.29) & $8.75(0.35)$ & 0.05 \\
\hline Albumin(g/L) & $42.97(0.13)$ & $42.80(0.14)$ & N.S. \\
\hline Globulins(g/L) & $30.33(0.19)$ & $29.47(0.05)$ & $<0.0001$ \\
\hline Albumin/Globulin Ratio & $1.45(0.01)$ & $\mathrm{I} .47(0.00)$ & 0.01 \\
\hline Globulin/Albumin Ratio & $0.72(0.01)$ & $0.69(0.00)$ & 0.02 \\
\hline Lymphocytes(x|0^9/L) & $2.41(0.03)$ & $2.26(0.01)$ & $<0.0001$ \\
\hline ALT (U/L) & $74.26(7.99)$ & $51.05(2.69)$ & $<0.01$ \\
\hline Cholesterol (mmol/L) & $4.48(0.04)$ & $4.77(0.14)$ & $<0.0001$ \\
\hline Urea (mmol/L) & $4.76(0.04)$ & $4.48(0.19)$ & $<0.0001$ \\
\hline Creatinine $(\mathrm{mcmol} / \mathrm{L})$ & $81.93(0.49)$ & 78.91 (0.27) & $<0.0001$ \\
\hline IGFI (nmol/l) & $25.81(1.35)$ & $20.79(0.60)$ & $<0.002$ \\
\hline DHEAS (mcmol/l) & $5.81(0.44)$ & $4.89(1.01)$ & N.S. \\
\hline
\end{tabular}

Mean ( \pm S.E.).

cated biomarker of ageing in the context of addiction. Albumin is synthesized in the liver but was found to be identical in the two groups. Cholesterol, although not different in DA and GM, was noted to be above $4.2 \mathrm{mmol} / \mathrm{l}$ less frequently (Table 5) and to rise more rapidly with age despite a somewhat slower rise in BMI in the DA group (Additional File 1). It is conceivable then that the liver is a primary or secondary driver of other observed systemic changes as has been previously noted $[54,55]$.

The differences observed in the hormonal profiles are also of interest. Considerable research and community attention has surrounded DHEAS as a major adrenal androgen associated with age related changes $[56,57]$. Its levels may rise with immune stimulation [58,59]. DHEAS protects lymphocytes from apoptosis [60] and also LDL particles from pro-atherogenic oxidation [61]. DHEAS is also elevated by exercise [62] which may be higher in these patients. There was a suggestion that under 45 years DHEAS was higher in males and lower in females than controls (Figure 3) but these did not reach significance. Larger studies would likely have more statistical power to detect such alterations.

Similarly IGF1, the mammalian homologue of the invertebrate DAF-16, is one of the main hormones implicated in insulin - insulin-like-growth-factor signalling (IIS) pathway in the biology of ageing [63]. It was not possible to study insulin or C-protein levels as we did not have access to the fasting state in this group of outpatients. IGF1 is a key component of the longevity regulation system conserved from yeast to mammals, and has recently been implicated mechanistically in the pathogenesis of various experimental neurodegenerative disorders $[64,65]$. Higher levels of IGF1 in DA in this study are therefore conceptually provocative.

Whilst this study has the virtue of relatively large numbers in a single centre, it is not possible to delineate causal pathways from a purely empirical study of this nature. Clearly further experimental and clinical work would be required to formally evaluate this hypothesis. Furthermore it is unclear whether the pharmacology of addiction itself, or some other related lifestyle factor such as poverty, homelessness, imprisonment, poor nutrition or overdose is largely responsible for the observed effects. Nevertheless the apparent uniformity of results across diverse body sys-

Table 5: Laboratory parameter elevationsSelected results, patients $<45$ years

\begin{tabular}{|c|c|c|c|c|c|c|}
\hline PARAMETER & Addictst & Medicalt & $\%$ 's* & OR & $\mathrm{Cl}$ & $\mathrm{P}$ \\
\hline Age <45 Years & $739 / 798$ & $5834 / 11295$ & $92.6 \% / 51.7 \%$ & 11.72 & $8.90-15.47$ & $<0.0001$ \\
\hline Body Mass Index $>25$ & |48/297 & $35 / 53$ & $33.3 \% / 39.8 \%$ & 0.75 & $0.46-1.24$ & N.S. \\
\hline CRP $>6 I U / I$ & $81 / 73$ & $490 / 811$ & $52.6 \% / 37.7 \%$ & 1.84 & $1.30-2.60$ & $<0.0005$ \\
\hline $\mathrm{ESR}>30 \mathrm{~mm} / \mathrm{hr}$ & $13 / 155$ & $49 / 1159$ & $7.7 \% / 4.1 \%$ & 1.98 & $1.00-3.87$ & $<0.05$ \\
\hline Globulins >35. g/dl & $90 / 519$ & $503 / 4930$ & $14.8 \% / 9.3 \%$ & 1.70 & $1.32-2.18$ & $<0.0001$ \\
\hline Albumin > $42 \mathrm{~g} / \mathrm{dl}$ & $345 / 264$ & $3000 / 2433$ & $56.7 \% / 55.2 \%$ & 1.06 & $0.89-1.26$ & N.S. \\
\hline Globulin/Albumin Ratio >0.9 & $90 / 519$ & $503 / 4930$ & $14.8 \% / 9.3 \%$ & 1.69 & $|.2|-2.2 \mid$ & $<0.002$ \\
\hline Albumin/Globulin Ratio > 1.8 & $57 / 552$ & $495 / 4938$ & $9.4 \% / 9.1 \%$ & 1.03 & $0.76-1.39$ & N.S. \\
\hline Lymphocytes $>2.5 \times 10(9) / 1$ & $224 / 377$ & $128 \mid / 2748$ & $37.3 \% / 31.8 \%$ & 1.27 & $1.06-1.53$ & $<0.01$ \\
\hline $\mathrm{ALT}>90 \mathrm{IU} / \mathrm{I}$ & $105 / 505$ & $504 / 4920$ & $17.2 \% / 9.3 \%$ & 2.03 & $1.60-2.57$ & $<0.0001$ \\
\hline Cholesterol > $4.2 \mathrm{mmol} / \mathrm{l}$ & $347 / 263$ & $3593 / 1872$ & $56.9 \% / 65.8 \%$ & 0.67 & $0.56-0.80$ & $<0.0001$ \\
\hline Creatinine $>100 \mathrm{mcmol} / \mathrm{l}$ & $59 / 679$ & $272 / 5159$ & $8.0 \% / 5.0 \%$ & 1.65 & $1.22-2.23$ & $<0.001$ \\
\hline Urea $>5 \mathrm{mmol} / \mathrm{l}$ & $227 / 381$ & $1588 / 3727$ & $37.3 \% / 29.9 \%$ & $1.4 \mathrm{I}$ & $1.17-1.67$ & $<0.0002$ \\
\hline Urea/Creatinine Ratio $>6.5$ & $81 / 658$ & $288 / 5 \mid 40$ & II.0\%/5.3\% & 2.78 & $2.11-3.65$ & $<0.0001$ \\
\hline Creatinine/Urea $>22$ & $134 / 605$ & $1251 / 4177$ & $18.1 \% / 23.0 \%$ & 0.74 & $0.60-0.91$ & $<0.005$ \\
\hline IGFI >30 nmol/I & $19 / 40$ & $21 / 162$ & $32.2 \% / 11.5 \%$ & 3.66 & $|.70-7.9|$ & $<0.0002$ \\
\hline DHEAS > 6 noml/l & $30 / 40$ & $57 / 109$ & $42.9 \% / 34.3 \%$ & 1.54 & $0.78-2.64$ & N.S. \\
\hline
\end{tabular}

† - Cells in these columns represent the numbers greater and less than the defined cut-off point.

* - Relates to Percentages in Addicts Vs. Medical Patients 

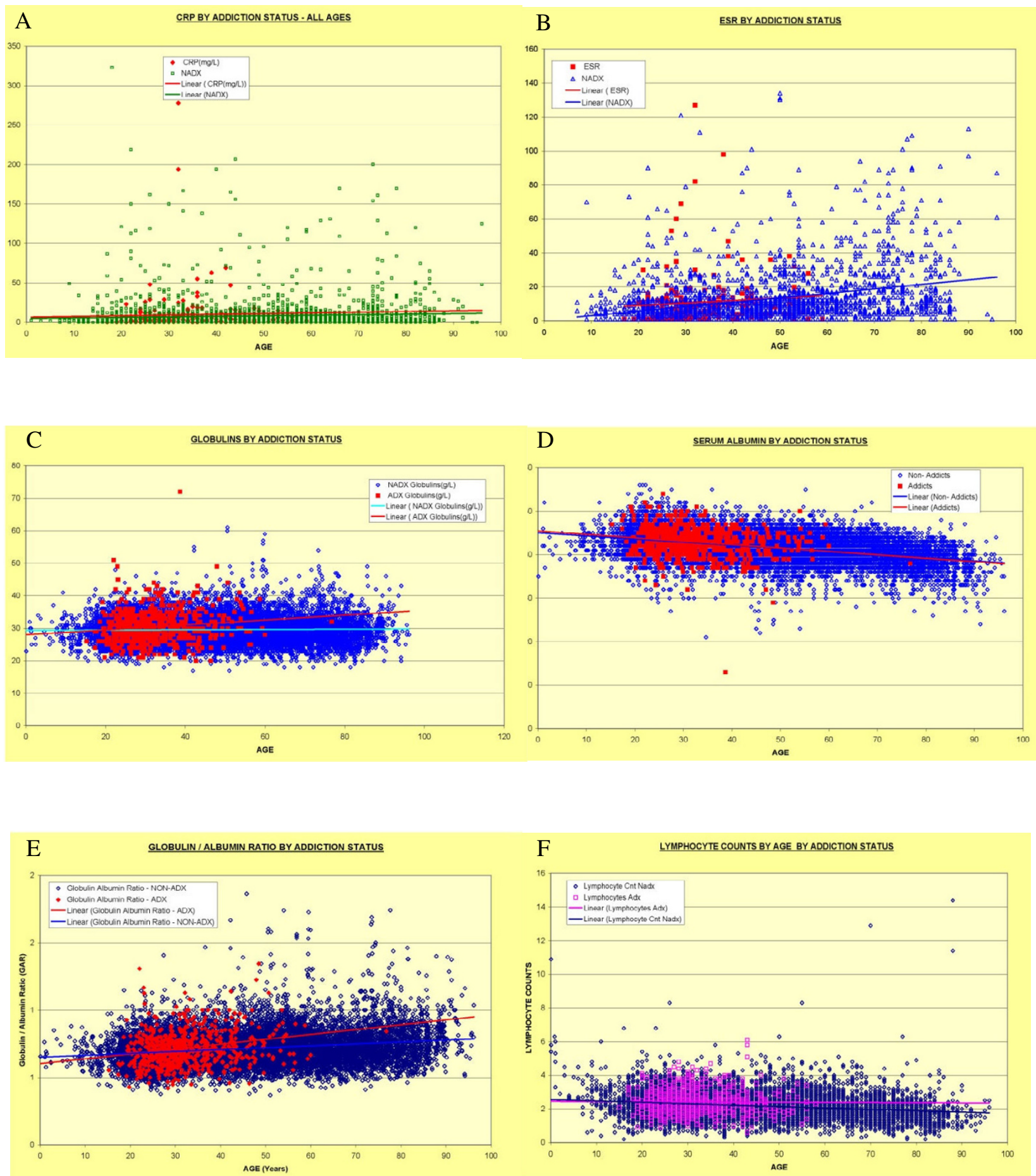

Figure I

Laboratory Parameters of Addiction, All Ages: Part I - Immunity. A: C-reactive Protein - CRP; B: Erythrocyte Sedimentation Rate - ESR; C: Globulins; D: Albumin; E: Albumin Globulin Ratio; F: Lymphocyte Count 

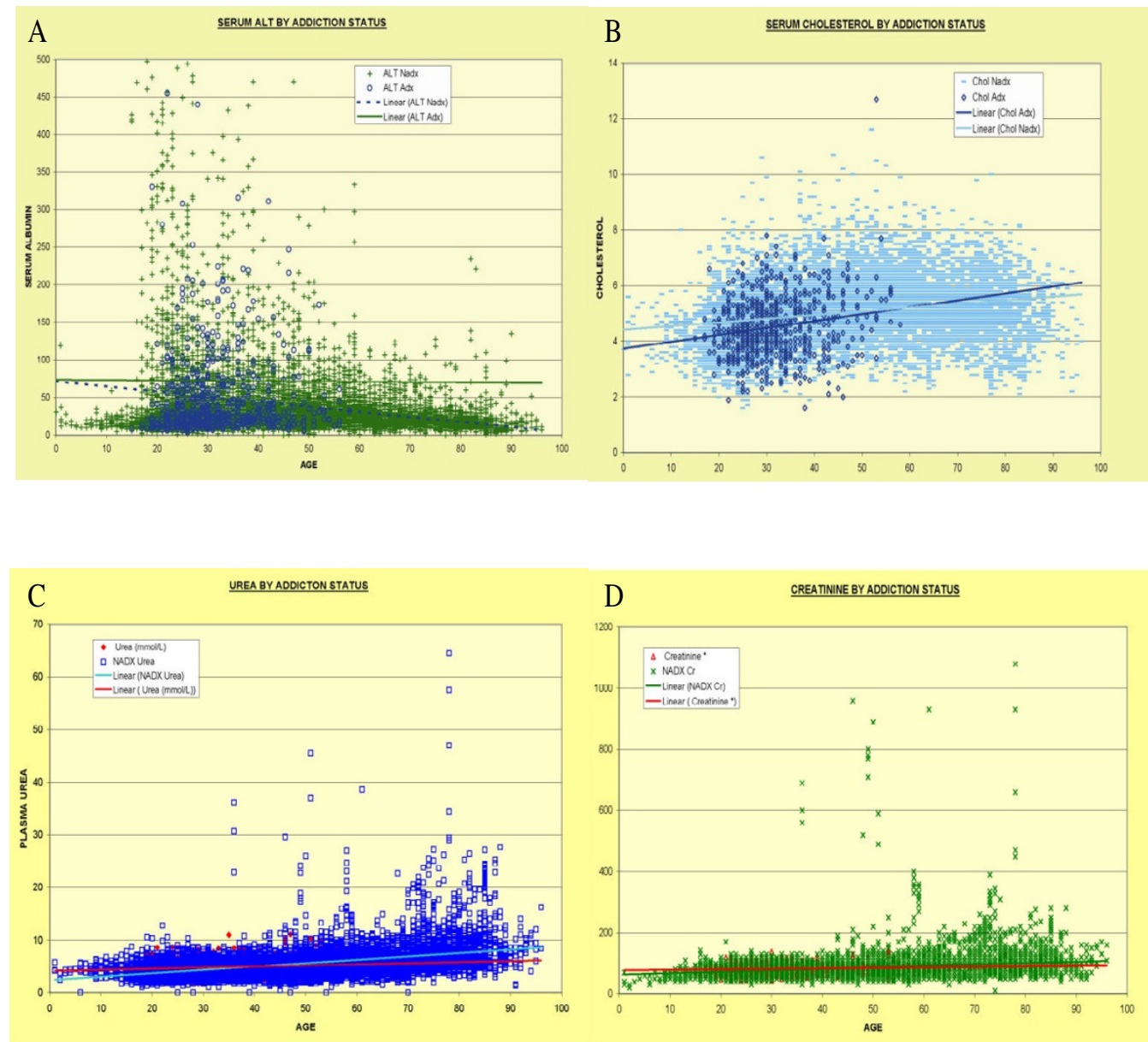

E

DHEAS BY ADDICTION STATUS

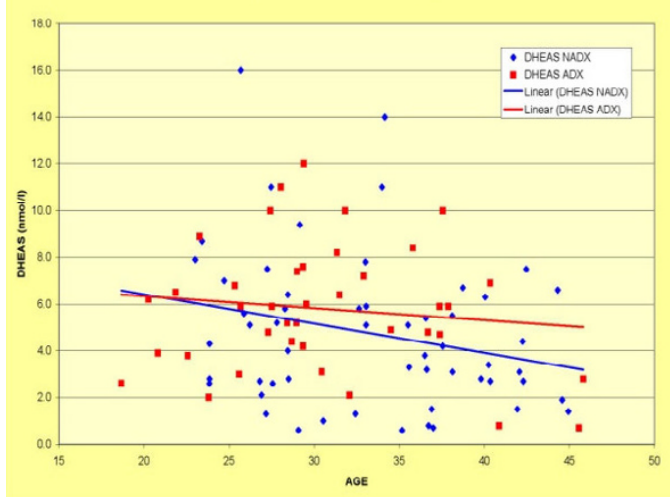

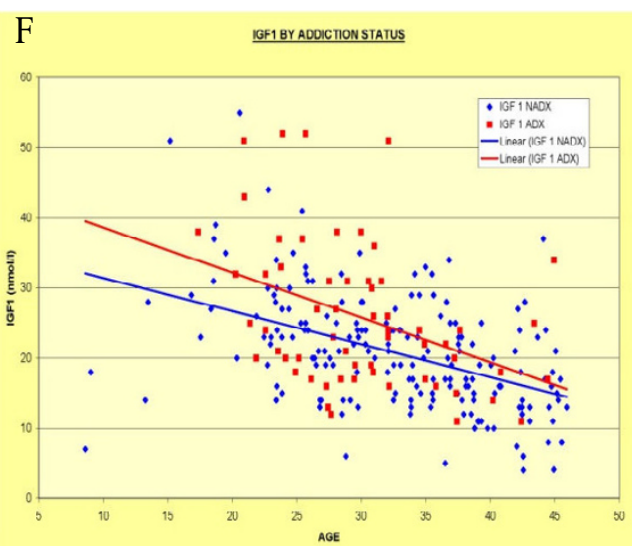

Figure 2

Laboratory Parameters of Addiction, All Ages: Part II - Metabolic. A: Alanine Aminotransferase - ALT; B: Cholesterol; C: Urea; D: Creatinine; E: DHEAS; F: Insulin Like Growth Factor-I 

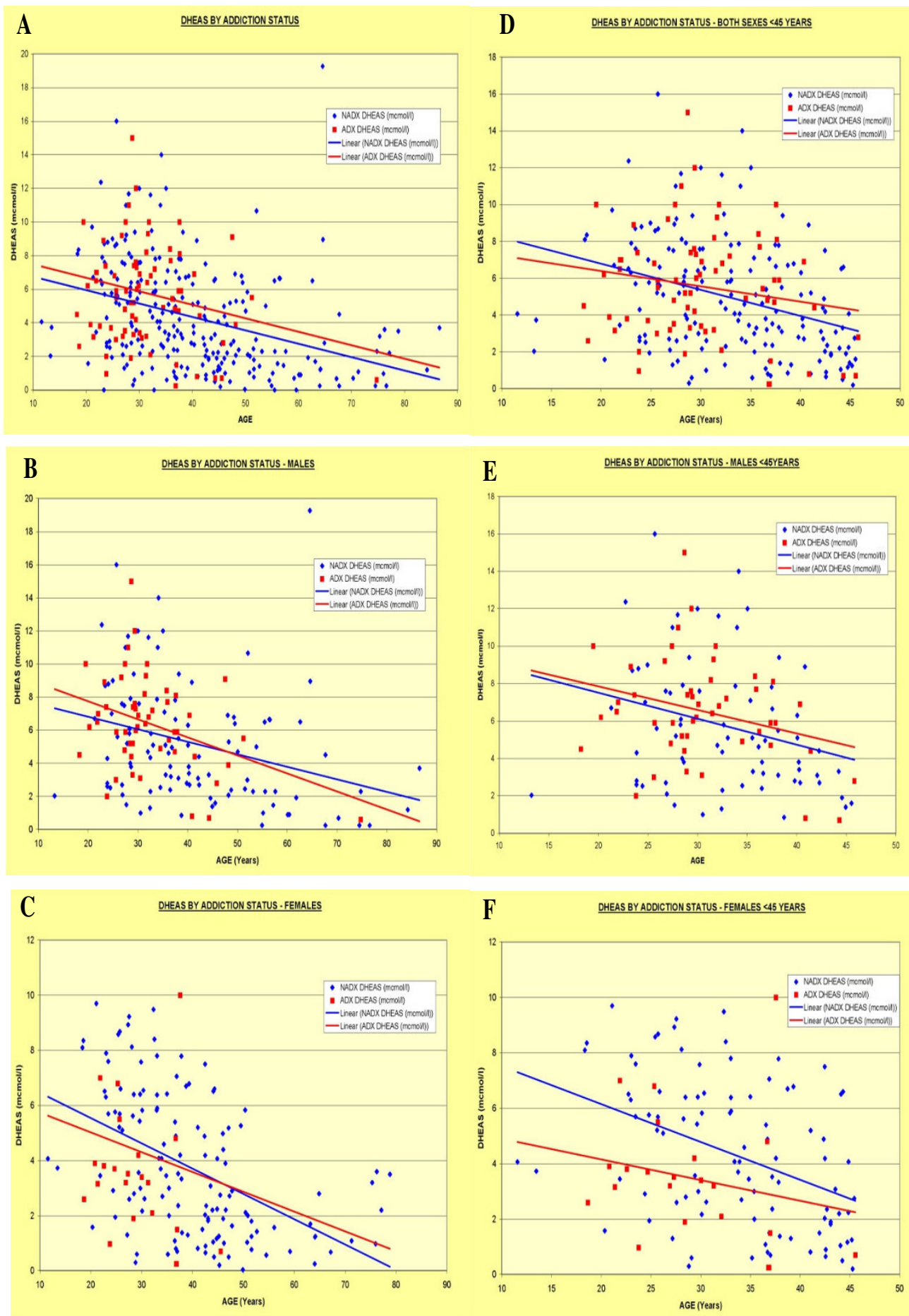

\section{Figure 3}

DHEAS by addiction status and age and sex groups. A: All Ages Both Sexes; B: Males of all ages; C: Females of all ages; D: both Sexes <45 Years; E: Males < 45 Years; F: Females < 45 Years. 
the use of medical patients as controls. It would be an advantage if future funded clinical studies had detailed information of patients' drug use available for all samples to allow multivariate association studies to be performed, and formal assignment of patients' addiction status.

This work would appear to invite further clinical and laboratory based investigations of the dynamic interaction between addiction and ageing, with the hope that improved understanding of these related disorders can improve our clinical management of ageing and addicted populations, and our understanding of the role of immune suppression and hyperstimulation in the ageing process.

\section{Additional material}

\section{Additional file 1}

Supplementary Figure 1. Clinical Pathological Indices <45 Years. A: Creactive protein - CRP. B: Erythrocyte Sedimentation Rate-ESR. C: Globulins. D: Albumin. E: Albumin/Globulin Ratio. F: Globulin/Albumin Ratio. G: Lymphocyte Count. H: Alanine Aminotransferase - ALT. I: Cholesterol. J: Creatinine. K: Urea. L: Creatinine/Urea Ratio. M: Body Mass Index - BMI. N: Body Mass Index, All Ages.

Click here for file

[http://www.biomedcentral.com/content/supplementary/17424933-4-6-S1.ppt]

\section{References}

I. Dattani MT, Brook CGD: Adolescent Health Problems. In Harrison's Principles of Internal Medicine Volume 8. I5th edition. Edited by: Braunwald E, Fauci AS, Kasper DL, Longo DL, Hauser SL, Jameson JL. McGraw-Hill Medical Publishing division. New York, Sydney; 200I.

2. Drug Abuse in Nine Cities. In NIDA Research Monograph 29, NTIS PB 80178882 Edited by: Gottschalk LA, McGuire FL, Heiser JF, Dinovo EC, Birch H. U.S. Government Printing Office, Department of Health and Human Services; 1979.

3. Darke S, Degenhardt L, Mattick R: Mortality amongst illicit drug users: epidemiology, causes and intervention. Cambridge, Cambridge University Press; 2007.

4. Gronbladh L, Gunne L: Methadone-assisted rehabilitation of Swedish heroin addicts. Drug Alcohol Depend 1989, 24:31-7.

5. Eisch AJ, Mandyam CD: Drug Dependence and Addiction II: Adult Neurogenesis and Drug Abuse. Am J Psychiatry 2004, | 6 1:426.

6. Yamaguchi M, Suzuki T, Seki T, Namba T, Juan R, Arai H, Hori T, Asada $T$ : Repetitive cocaine administration decreases neurogenesis in the adult rat hippocampus. Ann NY Acad Sci 2004, 1025:351-362.

7. Zagon IS, Verderame MF, McLaughlin PJ: The biology of the opioid growth factor receptor (OGFr). Brain Res Brain Res Rev 2002, 38:35I-76.

8. Park I, Morrison SJ, Clarke MF: Bmil, stem cells, and senescence regulation. J Clin Invest 2004, I I 3: I75-179.

9. Molofsky AV, Slutsky SG, Joseph NM, He S, Pardal R, Krishnamurthy J, Sharpless NE, Morrison SJ: Increasing p I6INK4a expression decreases forebrain progenitors and neurogenesis during ageing. Nature 2006, 443:448-52.

10. Mao J, Sung B, Ji R-R, Lim G: Neuronal apoptosis associated with morphine tolerance for an opioid-induced neurotoxic mechanism. J Neurosci 2002, 22:7650-766I.

II. Maccarrone M, Lorenzon T, Bari M, Melino G, Finazzi-Agro A: Anandamide induces apoptosis in human cells via vanilloid recep- tors. Evidence for a protective role of cannabinoid receptors. J Biol Chem 2000, 275:31938-45.

12. Bari M, Battista N, Fezza F, Finazzi-Agro A, Maccarrone M: Lipid Rafts control signalling of type-I cannabinoid receptors in neuronal cells. Implications for anandamide induced apoptosis. J Biol Chem 2005, 280: I2212-12220.

13. Krasnova IN, Ladenheim B, Cadet JL: Amphetamine induces apoptosis of medium spiny striatal projection neurons via the mitochondria-dependent pathway. FASEB / 2005, 19:85 I-3.

14. Li G, Xiao Y, Zhang L: Cocaine induces apoptosis in fetal rat myocardial cells through the $\mathbf{p} 38$ mitogen-activated protein kinase and mitochondrial/cytochrome c pathways. J Pharmacol Exp Ther 2005, 3 I 2: I I2-9.

I5. Campisi J: Senescent cells, tumor suppression, and organismal ageing: good citizens, bad neighbors. Cell 2005, I 20:5 I 3-22.

16. Herbig U, Ferriera M, Condel L, Carey D, Sedivy JM: Cellular Senescence in Ageing Primates. Science Express [http://www.sciencex press.org/2February 2006/Page I/I0.1 |26/science. I|22446]. viewed $12^{\text {th }}$ February 2006

17. Lombard DB, Chua KF, Mostoslavsky R, Franco S, Gostissa M, Alt FW: DNA repair, genome stability, and ageing. Cell 2005, I 20:497-5 I 2 .

18. Australian Government Department of Health and Ageing National Co-morbidity Initiative Viewed 26/I I/06 [http:// www.health.gov.au/internet/wcms/publishing.nsf/content/healthpubhlth-strateg-comorbidity-index.htm\#publications]

19. Gerstein D, Townsend TN, Lane JD, Dewar CS, Brittingham AM, Pergamit M: Substance Use and Mental Health Characteristics by employment Status. Department of Health and Human Services, Substance Abuse and Mental Health Services Administration (SAMSHA) USA Government 1999.

20. Callaly T, Trauer T, Munro L, Whelan G: Prevalence of psychiatric disorder in a methadone maintenance population. Aust N Z J Psychiatry 200I, 35:601-5.

21. Lai S, Lima JA, Lai H, Vlahov D, Celentano D, Tong W, Bartlett JG, Margolick J, Fishman EK: Human immunodeficiency virus I infection, cocaine, and coronary calcification. Arch Intern Med 2005, I 65:690-5.

22. Wang M, Zhang J, Spinetti G, Jiang LQ, Monticone R, Zhao D, Cheng L, Krawczyk M, Talan M, Pintus G, Lakatta EG: Angiotensin II activates matrix metalloproteinase type II and mimics age-associated carotid arterial remodeling in young rats. Am J Pathol 2005, I 67(5): | 429-42.

23. Kim TW, Alford DP, Malabanan A, Holick MF, Samet JH: Low bone density in patients receiving methadone maintenance treatment. Drug Alcohol Depend 2006, 85:258-62.

24. Idris Al, van 't Hof RJ, Greig IR, Ridge SA, Baker D, Ross RA, Ralston $\mathrm{SH}$ : Regulation of bone mass, bone loss and osteoclast activity by cannabinoid receptors. Nat Med 2005, I I(7):774-9.

25. Huang HFS, Nahas GG, Hembree WC: Effects of Marijuana inhalation on spermatogenesis of the rat. In "Marijuana and Medicine" Volume 28. Humana Press Totowa, New Jersey; 1999:PP359-366.

26. Hembree WC, Nahas GG, Zeidenberg P, Huang HFS: Changes in Human Spermatozoa Associated with High Dose Marihuana Smoking. In "Marijuana and Medicine" Volume 29. Humana Press Totowa, New Jersey; 1999:PP367-378. Figure 8 P 377

27. Reece AS: Hair Graying in Substance Addiction. Arch Derm 2007, 143: I 16-I I8.

28. Reece AS: Dentition of Addiction in Queensland: Poor Dental Status and Major Contributing Drugs. Aust Dent J in press. accepted 23/10/06

29. Osborn M, Butler T, Barnard PD: Oral health status of prison inmates-New South Wales, Australia. Aust Dent $J 2003$, 48:34-8.

30. Wang J, Charboneau R, Balasubramanian S, Barke RA, Loh HH, Roy $S$ : The immunosuppressive effects of chronic morphine treatment are partially dependent on corticosterone and mediated by the mu-opioid receptor. J Leukoc Biol 2002, 7 1:782-90.

31. McCarthy L, Wetzel M, Sliker JK, Eisenstein TK, Rogers TJ: Opioids, opioid receptors, and the immune response. Drug Alcohol Depend 2001, 62: III-23.

32. Suzuki S: Methadone Induces CCR5 and Promotes AIDS Virus infection. FEBS Lett 2002, 5 I9(I-3): I73-I77. 
33. Pillai R, Nair BS, Watson RR: AIDS, drugs of abuse and the immune system: a complex immunotoxicological network. Arch Toxicol 1991, 65:609-17.

34. Li Y, Wang X, Tian S, Guo CJ, Douglas SD, Ho WZ: Methadone enhances human immunodeficiency virus infection of human immune cells. J Infect Dis I 85(I): I |8-22. 2002 Jan I

35. Pawelec G, Koch S, Griesemann H, Rehbein A, Hahnel K, Gouttefangeas C: Immunosenescence, suppression and tumour progression. Cancer Immunol Immunother 2006, 55:98I-6.

36. Nasi M, Troiano L, Lugli E, Pinti M, Ferraresi R, Monterastelli E, Mussi C, Salvioli G, Franceschi C, Cossarizza A: Thymic output and functionality of the IL-7/IL-7 receptor system in centenarians: implications for the neolymphogenesis at the limit of human life. Ageing Cell 2006, 5: 167-75.

37. Hansson GK: Inflammation, atherosclerosis, and coronary artery disease. N Engl J Med 2005, 352: I685-95.

38. Marin-Teva JL, Dusart I, Colin C, Gervais A, van Rooijen N, Mallat M: Microglia promote the death of developing Purkinje cells. Neuron 2004, 41:535-47.

39. Hussain SP, Hofseth LJ, Harris CC: Radical causes of cancer. Nat Rev Cancer 2003, 3:276-85.

40. Carney ST, Lloyd ML, Howlett A, Norford DC: CannabinoidInduced NO Production in NI8TG2 neuronal cells. Abstract 97 Presented at: International Cannabinoid Research society Meeting Tampa Florida 2005.

4I. Sarafian T, Habib N, Oldham M, Lin L, Kurek L, Seeram NP, Lee RP, Tashkin DP, Roth MD: Inhaled marijuana smoke alters mitochondrial function in airway epithelial cells in vivo. Abstract I55 Presented at: International Cannabinoid Research society Meeting Tampa Florida 2005.

42. Hadley EC, Lakatta EG, Morrison-Bogorad M, Warner HR, Hodes RJ: The future of ageing therapies. Cell 2005, I 20:557-67.

43. Smucny DA, Allison DB, Ingram DK, Roth GS, Kemnitz JW, Kohama SG, Lane MA, Black A: Changes in blood chemistry and hematology variables during ageing in captive rhesus macaques (Macaca mulatta). J Med Primatol 2001, 30:161-173.

44. Sansoni $P$, Franceschi $C$, et al:: Lymphocyte subsets and natural killer cell activity in healthy old people and centenarians. Blood 1993, 82:2767-2773.

45. Franceschi C, Monti D, Sansoni P, Cossarizza A: The immunology of exceptional individuals: the lesson of centenarians. Immunology today 1995, 16:12-16.

46. Franceschi C, Bonafe M, Valensin S, Olivieri F, et al.: Inflamm-aging: an evolutionary perspective of Immunosenescence. Ann NY Acad Sci 2000, 908:244-254

47. Nair M, Salvioli G, Franceschi C, Cossarizza A, et al:: Thymic output and functionality of the IL-7/IL-7 receptor system in centenarians: implications for the neolymphogenesis at the limit of human life. Aging cell 2006, 5:167-175

48. De Martinis M, Fanceschi C, Monti D, Ginaldi L: Imflamm-aging and lifelong antigenic load as major determinants of the ageing rate and longevity. FEBS Lett 2005, 579:2035-2039.

49. Ginaldi L, De Martinis M, Monti D, Franceschi C: The immune system in the elderly. Activation-induced and damage induced apoptosis. Immunologic Res 2004, 30:8I-94.

50. Franceschi $C$, Bonafe $M$, Valensin S: Human Immunosenescence: the prevailing of innate immunity, the failing of clonotypic immunity, and the filling of the immunological space. Vaccine 2000, I 8: I7|7-1720.

51. Vasto S, Grimaldi MP, Caruso C, et al.: Inflammatory networks in ageing, age related diseases and longevity. Mech Ageing and Development 2007, | 28:83-91.

52. Salvioli S, Capri M, Valensin S, Tieri P, Monti D, Ottaviani E, Franceschi $C$ : Inflamm-aging, cytokines and aging: state of the art, new hypotheses on the role of mitochondria and new perspectives from systems biology. Curr Pharmaceutical Design 2006, |2:3|6|-3|7|.

53. Bianchi T, Rufer N, Macdonald HR, Migliaccio M: The tumour suppressor p I 6 ${ }^{\mathrm{N} K 4 a}$ regulates $\mathrm{T}$ lymphocyte survival. Oncogene 2006, 25:4II0-4II5.

54. Le Couteur DG, Fraser R, Hilmer S, Rivory LP, McLean AJ: The hepatic sinusoid in ageing and cirrhosis. Clin Pharmacokinet 2005, 44: 187-200.

55. Warren A, Bertolino P, Bensler V, Fraser R, McGaughan GW, Le Couteur DG: Marked changes of the hepatic sinusoid in a transgenic model of acute immune mediated hepatitis. Hepatology 2007, 46:239-246.

56. Fonda SJ, Bertrand R, O'Donnell A, Longcope C, McKinlay JB: Age, hormones, and cognitive functioning among middle-aged and elderly men: cross-sectional evidence from the Massachusetts Male Ageing Study. J Gerontol A Biol Sci Med Sci 2005, 60:385-90.

57. Leowattana W: DHEA(S): the fountain of youth. J Med Assoc Thai 200I, 84(Suppl 2):S605-I2

58. Maes M, Mihaylova I, De Ruyter M: Decreased dehydroepiandrosterone sulfate but normal insulin-like growth factor in chronic fatigue syndrome (CFS): relevance for the inflammatory response in CFS. Neuro Endocrinol Lett 2005, 26(5):487-92.

59. Gelinas DS, McLaurin J: PPAR-alpha expression inversely correlates with inflammatory cytokines IL-I beta and TNF-alpha in ageing rats. Neurochem Res 2005, 30( I I): I 369-75.

60. Takahashi H, Nakajima A, Sekihara H: Dehydroepiandrosterone (DHEA) and its sulfate (DHEAS) inhibit the apoptosis in human peripheral blood lymphocytes. I Steroid Biochem Mol Biol 2004, 88(3):26I-4

6I. Khalil A, Fortin JP, LeHoux JG, Fulop T: Age-related decrease of dehydroepiandrosterone concentrations in low density lipoproteins and its role in the susceptibility of low density lipoproteins to lipid peroxidation. J Lipid Res 2000, 4 I (I 0): I 552-6 I.

62. Tissandier O, Peres G, Fiet J, Piette F: Testosterone, dehydroepiandrosterone, insulin-like growth factor $I$, and insulin in sedentary and physically trained aged men. Eur J Appl Physiol 200 I, 85(I-2): 177-84.

63. Guarente L, Picard F: Calorie Restriction - the SIR2 Connection. Cell 2005, I 20:473-482.

64. Cohen E, Bieschke J, Perciavalle RM, Kelly JW, Dillin A: Opposing activities protect against age-onset proteotoxicity. Science 2006, 3 I 3:1604-10.

65. Morimoto RI: Stress Ageing and Neurodegenerative disease. $N$ Engl J Med 2006, 355:2254-2255

Publish with Bio Med Central and every scientist can read your work free of charge

"BioMed Central will be the most significant development for disseminating the results of biomedical research in our lifetime. "

Sir Paul Nurse, Cancer Research UK

Your research papers will be:

- available free of charge to the entire biomedical community

- peer reviewed and published immediately upon acceptance

- cited in PubMed and archived on PubMed Central

- yours - you keep the copyright
BioMedcentral 